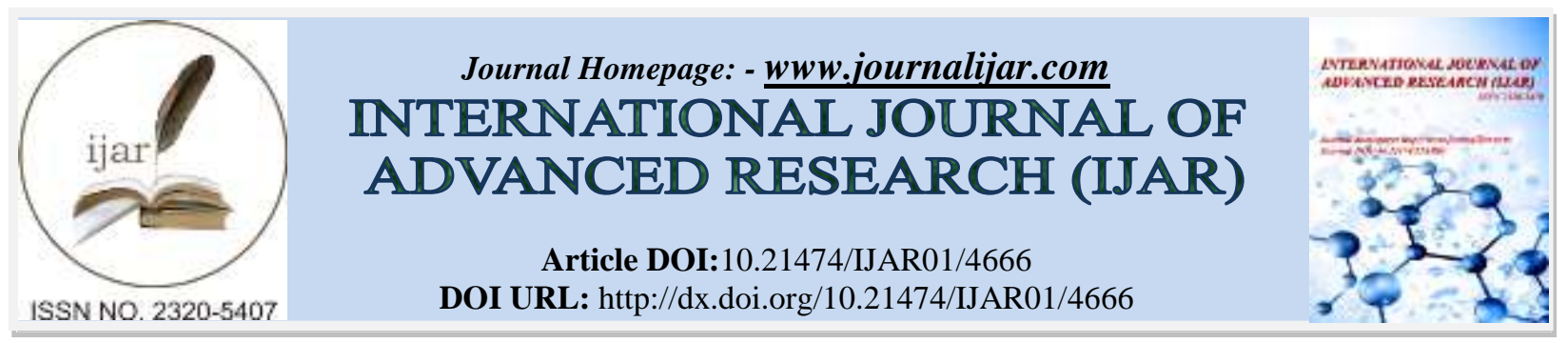

RESEARCH ARTICLE

\title{
EVALUATION OF VARIABILITY IN LAWSONIA INERMIS L. USING MORPHOLOGICAL AND BIOCHEMICAL MARKERS.
}

Panambatta Challakkal Shiji and Elenjikkal Avarachan Siril*

Department of Botany, University of Kerala, Kariavattom, Thiruvananthapuram-695 581, Kerala, India.

\section{Manuscript Info}

\section{Manuscript History}

Received: 25 April 2017

Final Accepted: 30 May 2017

Published: June 2017

Key words:-

Analysis of variance, Biochemical variability, Lawsonia inermis $\mathrm{L}$. Morphological variability, Principal component analysis

\section{Abstract}

Lawsonia inermis (henna) is a commercially important dye yielding small tree distributed in arid and semi arid regions of the tropics. This study was conducted for comparing the morphological characteristics of $L$. inermis collections. In the present study seventeen collections of L. inermis from various parts of Kerala State, India were evaluated on the basis of seventeen quantitative morphological traits and lawsone content. One way ANOVA on all the quantitative traits showed significant variations. The dendrogram generated on the basis of metric traits revealed collection L6 and L14 formed as a diverged distinct cluster from all other genotypes. Principal components analysis was performed to identify the significant characters and it revealed that quantitative characters like length of leaf $(0.511 \mathrm{~mm})$, width of leaf $(0.388 \mathrm{~mm})$, diameter of corolla $(0.283 \mathrm{~mm})$, length of fruit $(0.282 \mathrm{~mm})$, width of fruit $(0.271 \mathrm{~mm})$ and diameter of calyx $(0.258 \mathrm{~mm})$. Biochemical character viz., lawsone content was significantly $(\mathrm{P}<0.05)$ high in collection $\mathrm{L} 14$. The variability records in L. inermis can be implied to screen superior germplasm on the basis of desirable quality traits such as leaf characters and lawsone content. The present study clearly emphasis the ability of morphological markers in characterization and utilization of plant genetic resource.

\section{Introduction:-}

Lawsonia inermis (common name: Henna), is a small evergreen tree native to North Africa and South-West Asia. It is commercially important due to its leaf, which contains an active, naphthoquinone based, dye (red orange pigment), lawsone (2- hydroxy-1:4 napthoquinone). Physical conditions influence the dye properties and percentage of lawsone in henna (Bakkali et al. 1997). Normally the concentration of lawsone found in leaves ranges between 0.5-1.5\% (Gallo et al. 2008). In Kerala, the southernmost state of India, henna is maintained in the home gardens as ornamental plant and for the preparation of household, traditional cosmetics. The plant is however, cultivated in northern India, the Middle East and along the African coast of the Mediterranean Sea (Chaudhary et al. 2010). It thrives well in climate with annual rainfall of 200-4200 $\mathrm{mm}$ and an extended dry season, even with poor semi dry soil in range of $\mathrm{pH} 4.3$ to 8 .

Corresponding Author:-Elenjikkal Avarachan Siril.

Address:-Department of Botany, University of Kerala, Kariavattom, Thiruvananthapuram-695 581,

Kerala, India. 
Morphologically, it has been identified as a small tree (5-6m height) with highly branched tree architecture. Leaves are small, opposite in arrangement along the branches, sub-sessile, about 1.5 to $5 \mathrm{~cm}$ long, 0.5 to $2 \mathrm{~cm}$ wide, greenish brown to dull green, elliptic to broadly lanceolate with entire margin, petiole short and glabrous and acute or obtuse apex with tapering base. Young branches are green in color and quadrangular which turn reddish brown with age. Bark is greyish brown, unarmed when young but branches of older trees are spine tipped. Inflorescence is a large pyramid shaped cyme. Flowers are small, about $1 \mathrm{~cm}$ across numerous, fragrant, white or rose colored with four crumbled petals. Calyx is with a $0.2 \mathrm{~cm}$ tube and $0.3 \mathrm{~cm}$ spread lobes. Fruit is a small brown coloured round capsule. Fruit opens irregularly and splits into four sections at maturity and is many seeded. Henna seeds are straw to dark brown in colour, small (1-2 mm long), hard and wedge-shaped. They are borne in small globular capsules exhibiting polymorphism in size. Seeds are numerous, smooth, pyramidal, hard and thick seed coat with brownish coloration.

Henna is now well recognized as a valuable resource for the preparation of cosmetics such as natural hair dye, dyeing skin, nails etc. People perceive that henna as a natural product without having any adverse effect. Demand of henna is increasing worldwide, due to its multipurpose uses in cosmetic and pharmaceutical industries (Chand and Jangid 2007). However, quality of the henna is determined by the content of dye and economic status of $L$. inermis cultivation is depending on net biomass and dye yield. The present study was under taken to estimate extent of variability present in L. inermis distributed in the region. It is also intended to select the superior eco-types for their use in breeding programmes and mass propagation. Collections from different parts of Kerala state were characterized morphologically and biochemically for the assessment of naturally occurring variability among different collections.

\section{Materials and Methods:- Plant Collection:-}

L. inermis was collected from different localities of Kerala state, India (Table 1). From each locality, shoots were randomly sampled and brought to the Department of Botany, University of Kerala, Kariavattom. The collections were planted in clay pots filled with soil and farmyard manure (1:1) and maintained in the Department garden (8'33'03.86"North latitude and 7652'38.64" East longitude located at an altitude of $18 \mathrm{~m}$ asl.).

\section{Analysis of quantitative Characters:-}

Metric morphological traits such as Leaf length (LL), Leaf width (LW), Length of petiole (LP), Leaf biomass (LB), Length of petal(LPT),Width of petal (WPT), Diameter of corolla (DCO), Length of sepal (LS), Width of sepal (WS), Diameter of calyx (DCL), Length of peduncle (LPD), Fruit length (LF), Fruit width (WF), Fruit weight (FWT), Seed length (SL), Seed width (SW), Seed weight (SWT) were measured for different collections.

\section{Quantification of lawsone:-}

For the quantification of lawsone, fresh leaves were collected and shade dried for seven days. The dried leaves were grinded in to fine powder and used for the extraction of dye. Dried powdered leaves (100mg) of L. inermis were soaked in $10 \mathrm{ml}$ methanol for $2 \mathrm{hrs}$ and then, the mixture was centrifuged at 5000rpm for 20 min and the clear supernatant was separated out in to an empty clean dried boiling tube. The quantification of lawsone was carried out as reported earlier (Anju et al. 2012). The absorbance of supernatant was read out at 452nm using UV-VIS spectrophotometer (Shimadzu, Japan). The quantification was made on the basis of pure standard of lawsone (SIGMA CHEM., ST. LOUIS, US). The lawsone content in dried leaves was calculated in $\mathrm{mg} / \mathrm{ml}$.

\section{Data analysis:-}

Analysis of Variance (ANOVA)

Data on metric morphological traits were recorded by scoring ten observations and the collected data subjected to one-way analysis of variance using an SPSS package version 7.5 (SPSS Inc., Chicago, IL, USA) to find out variations in quantitative and biochemical characters.

\section{Principal component analysis (PCA):-}

PCA (Pearson 1901) is a vector space transform often used to reduce multidimensional data sets to lower dimensions for analysis. It is mostly used as a tool in exploratory data analysis and for making predictive models. PCA involves the calculation of the eigenvalue decomposition of a data covariance matrix or singular value decomposition of a data matrix usually after mean centering the data for each attribute. The results of the PCA are 
usually discussed in terms of component scores and loadings. In the present study PCA is employed for determining the significance and efficiency of quantitative characters for the species level systematics in L. inermis.

\section{Cluster Analysis:-}

Cluster analysis was performed on the basis of genetic similarity matrix, and the resulting similarity coefficients were used for constructing dendrogram using the Unweighted Pair Group Method with Arithmetic Average (UPGMA) using the Multivariate Statistical Package MVSP version 3.1 (Kovach computing services, Wales, UK). It is used to group organisms in to separate cluster based on their statistical behaviour. The main objective of clustering is to find similarities between organism, and then group similar organisms together to assist in understanding relationship that might exist among them. In the present study, the unweighted pair-group method using arithmetic averages (UPGMA) is used for the clustering of 17 collections (LI) of genus L. inermis.

\section{Principal coordinate Analysis (PCoA):-}

Principal component analysis followed by construction of scatter plot based on ordination of collections was performed. This is an ordination technique developed by Gower (1966) which determines the placement of collections in two-dimensional or three-dimensional space. The result of two-dimensional ordination is conveniently represented with the help of a scatter diagram. The technique enables computation of principal components of any distance matrix without being in possession of original data matrix. The distribution of collections in the scatter plot is a direct indication of the extent of relation existing among them and so it is used as a supporting and correcting tool of UPGMA phenogram.

\section{Result and Discussion:-}

\section{Evaluation of morphological variation based on quantitative traits of $L$. Inermis:-}

Observations on seventeen qualitative traits were recorded for all the 17 genotypes of L. inermis. Morphometric characters on both vegetative as well as reproductive parts were recorded and tabulated (Table 2-5). In the present study, significant variations were found in morphometric traits of leaf, flower, fruit and seed morphology. Maximum variation observed in the leaf morphological parameters in terms of leaf length, width of leaf, biomass of leaf and length of petiole compared to the other morphometric parameters.

Leaf parameter such as leaf biomass varied significantly among most of the collections studied $(\mathrm{P}<0.01)$. Significantly $(\mathrm{P}<0.05)$ high leaf biomass was recorded in Idukki $(\mathrm{L} 10)$ collection $(0.123 \mathrm{gm})$. L3 and L13 collection was recorded the similar least biomass of leaf $(0.026 \mathrm{gm})$. The collections L16 and L17 show similar leaf biomass $(0.042 \mathrm{gm})$. Leaf length varied significantly $(\mathrm{P}<0.01)$ among all the accessions considered. Maximum leaf length $(52.67 \mathrm{~mm})$ was recorded in L1. Overall, length of leaf ranged from 21.47 to $52.67 \mathrm{~mm}$. Leaf length was significantly ( $\mathrm{P}<0.001)$ high in L1 and least in L13 collection $(21.47 \mathrm{~mm})$. Width of leaf varied significantly and highest was recorded in L1, L3 and L14 $(20.51,21.16$ and $20.35 \mathrm{~mm})$ collected from Trivandrum, Kollam and Wayanad. Collections L12, L15 and L16 did not show any significant variation in leaf width (Table 2). Length of petiole ranged from 2.43 to $7.94 \mathrm{~mm}$. Among the genotypes, leaf morphology shows a wide range in variations within the four parameters.

Length of sepal did not show any statistical significance, on the other hand width of sepal varied significantly $(\mathrm{P}<0.01)$. Length of sepal was highly recorded in L10 $(4.20 \mathrm{~mm})$ and least noticed in L1 $(2.81 \mathrm{~mm})$. Width of sepal ranged from 1.38 to $2.25 \mathrm{~mm}$. Significantly $(\mathrm{P}<0.05)$ high sepal width was recorded in L15 Wayanad collection (Table 3). Collections L3, L9, L11, L12 L17 collections did not show any significant variation in width of sepal (Table2).

Length of petal was high in L6 $(4.72 \mathrm{~mm})$ and least observed in L14 $(2.45 \mathrm{~mm})$. Likewise, diameter of calyx ranges from 3.59-6.11 mm and varied significantly $(\mathrm{P}<0.01)$ among collections. Measurements on diameter of corollavaried significantly $(\mathrm{P}<0.001)$ between collections (Table 4). Maximum diameter of corolla was recorded in Thrissur collection $(8.78 \mathrm{~mm})$.

Fruit length showed significant variation and highest recorded in L9 $(7.80 \mathrm{~mm})$ (Table 4). Fruit length ranges from $(4.70-7.80 \mathrm{~mm})$ among the genotype. Width of fruit was highest recorded in L16 $(7.78 \mathrm{~mm})$ and least in L6 $(1.58 \mathrm{~mm})$. Fruit weight varied significantly $(\mathrm{P}<0.001)$ among collections. Fruits of L9, L12, and L16 were significantly $(\mathrm{P}<0.05)$ heavier $(0.24 \mathrm{gm}, 0.24 \mathrm{gm}$ and $0.25 \mathrm{gm})$ than all other collections. 
Length and weight of seed varied significantly $(\mathrm{P}<0.001)$. Maximum length of seed was recorded in Trivandrum collection (Table 5). The weight of seed values ranges from 0.03-0.19g. Morphological traits provide a simple way of measuring genetic diversity and variations are influenced by environmental factors (Tuinstra et al. 1996; Beuningen and Busch 1997; Adbi et al. 2002; Fufa et al. 2005). Studies on germplasm characterization have been carried out frequently using characterization of plant morphological attributes (Rosso and Pagano 2001; Rubio et al. 2004; Ruiz and Egea 2008; Szamosi et al. 2009; Morris 2009; Elfadl et al. 2010; Nikolic et al. 2010; Gerrano et al. 2014). In the present study morphological characters were used for characterization of the collections of L. inermis. It showed variations in the quantitative aspects of the leaf morphology. Among the quantitative characters analysed, floral morphology, fruits and seed characters were also showed variations among the 17 collections. There was wide range of variability among different clones of L. inermis was previously reported by (Singh et al. 2008). Our results explain that morphological variation in the L. inermis collections may be strongly influenced by variation in growth traits and are associated with a latitudinal and attitudinal range or by distinct climatic conditions. The observed result of morphological variation made mention of adaptation to the contrasting micro-edaphic conditions prevailing for these groups and this may supported by the significant correlation with soil physicochemical characteristics. The greater discrimination power of adaptation to micro edaphic conditions compared to the geographical regions of origin of accession in this study clearly indicated the greater importance of environmental factors (soil texture, soil chemical characteristics, and annual rainfall) than geographical location, in discriminating populations. Human actions and natural selection factors, by affecting morphological traits related to adaptation of a population, could allow interference with adaptation due to genetic distances from quantitative traits. Studies on variations present in germplasm collections have been carried out by employing plant morphological attributes as characterization tool among Alfa alfa (Medicago sativa) (Rumbaugh et al. 1988), White clover (Trifolium repens) (Rosso and Pagano 2001), White lupin (Lupinus albus) (Rubio et al. 2004), Swordbean (Canavalia ensiformis) (Morris 2007), Horsegram (Macrotyloma axillare) (Morris 2008), Butterfly pea (Clitoria ternatea) (Morris2009), and Fenugreek (Trigonella foenum-graecum) (McCormick et al. 2009).

Thus in the present study variations in morphological traits were recorded and these variations were further analysed by principal component analysis (PCA).

Fig. 1:- UPGMA Dendrogram of the successive hierarchial joining deduced from standardized distances between population of L.inermis considering 17 quantitative characters., showing leaf, floral, fruit and seed morphological variability of different collections of L. inermis L1, L2, L3, L4, L5, L6, L7, L8, L9, L10, L11, L12, L13, L14, L15, L16, L17

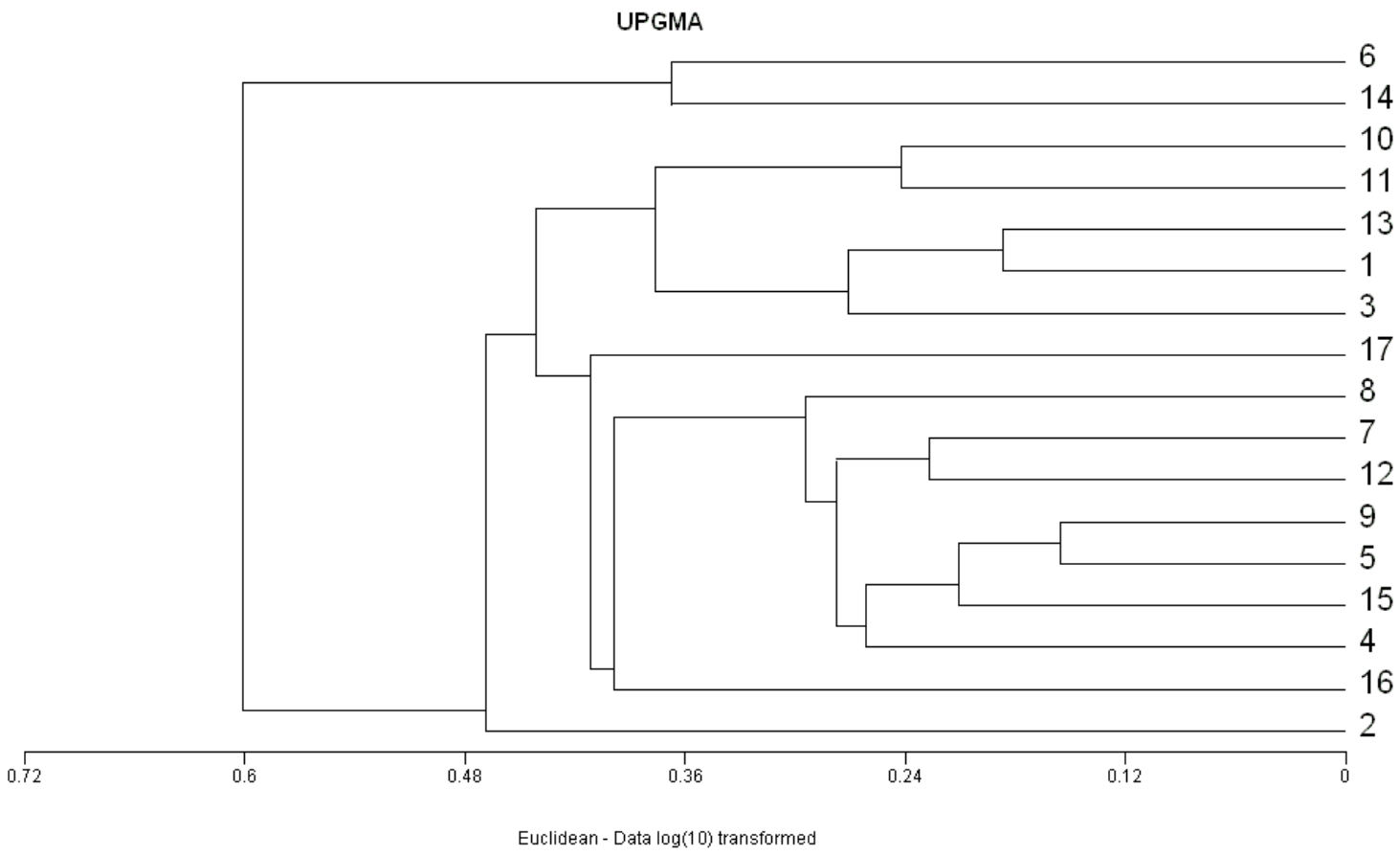


Fig. 2:- Scatter plot variables after PCA (Principle component analysis) showing the phenotypic variation among 17 collections of L.inermis.1) L1, L2, L3, L4, L5, L6, L7, L8, L9, L10, L11, L12, L13, L14, L15, L16, L17

\section{PCO case scores (Euclidean)}

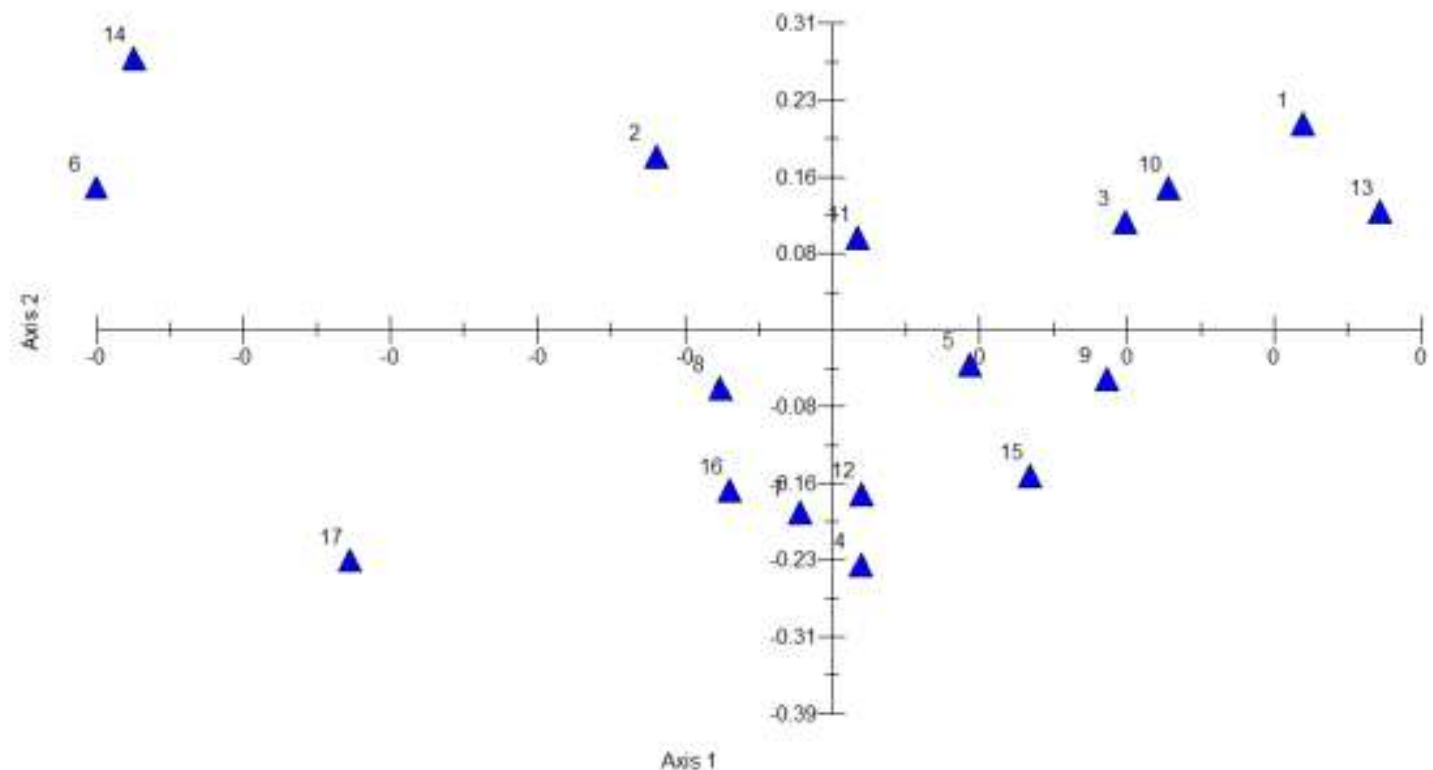

Table 1:- Various features of different collections selected for detailed analysis.

\begin{tabular}{|c|c|c|c|c|}
\hline Name of Accessions & Revenue District & Latitude & Longitude & Altitude (m) \\
\hline L1 & Trivandrum & $8^{\circ} 33^{\prime} 9.71^{\prime \prime} \mathrm{N}$ & $76^{\circ} 53^{\prime} 17.23$ ”E & 140 \\
\hline L2 & Trivandrum & $8^{\circ} 24^{\prime} 19.12^{\prime \prime} \mathrm{N}$ & $76^{\circ} 58^{\prime} 22.78^{\prime \prime} \mathrm{E}$ & 223 \\
\hline L3 & Kollam & 9०03'13.88’N & $76^{\circ} 32^{\prime} 08.15^{\prime \prime} \mathrm{E}$ & 3.8 \\
\hline L4 & Kollam & 859’42.19”'N & $76^{\circ} 46^{\prime} 40.38^{\prime \prime} \mathrm{E}$ & 152 \\
\hline L5 & Kollam & $9^{\circ} 23$ '41.87’"N & $76^{\circ} 38^{\prime} 38.15^{\prime \prime} \mathrm{E}$ & 18 \\
\hline L6 & Thrissur & $10^{\circ} 31^{\prime} 76.13 ” \mathrm{~N}$ & $76^{\circ} 01^{\prime} 50.08^{\prime \prime} \mathrm{E}$ & 9.3 \\
\hline L7 & Malappuram & $11^{\circ} 02^{\prime} 28.00^{\prime \prime} \mathrm{N}$ & 76'04'59.08’"E & 130 \\
\hline L8 & Palakkad & $10^{\circ} 36^{\prime} 58.38^{\prime \prime} \mathrm{N}$ & $76^{\circ} 28^{\prime} 19.89$ 'E & 64 \\
\hline L9 & Palakkad & $10^{\circ} 35^{\prime} 57.31^{\prime \prime N}$ & $76^{\circ} 28^{\prime} 90.19^{\prime \prime} \mathrm{E}$ & 85 \\
\hline L10 & Idukki & $9^{\circ} 45^{\prime} 0827$ 'N & $77^{\circ} 07^{\prime} 00.30$ 'E & 893 \\
\hline L11 & Malappuram & $11^{\circ} 02^{\prime} 28.00^{\prime \prime N}$ & $76^{\circ} 04^{\prime} 59.08^{\prime \prime} \mathrm{E}$ & 130 \\
\hline L12 & Calicut & $11^{\circ} 25^{\prime} 45.73^{\prime \prime} \mathrm{N}$ & $75^{\circ} 56^{\prime} 37.68^{\prime \prime} \mathrm{E}$ & 60 \\
\hline L13 & Kottayam & $9^{\circ} 35^{\prime} 45.799^{\prime \prime} \mathrm{N}$ & $76^{\circ} 31^{\prime} 13.70^{\prime \prime} \mathrm{E}$ & 86 \\
\hline L14 & Wayanad & $11^{\circ} 35^{\prime} 31.57^{\prime \prime} \mathrm{N}$ & $76^{\circ} 02^{\prime} 37.82^{\prime \prime} \mathrm{E}$ & 850 \\
\hline L15 & Wayanad & $11^{\circ} 40^{\prime} 28.13 ” \mathrm{~N}$ & 7608’37. 99”E & 774 \\
\hline L16 & Alapuzha & $9^{\circ} 13^{\prime} 00.47^{\prime \prime} \mathrm{N}$ & $76^{\circ} 27^{\prime} 33.12 ” \mathrm{E}$ & 11 \\
\hline L17 & Trivandrum & $8^{\circ} 34^{\prime} 12.28^{\prime \prime} \mathrm{N}$ & $76^{\circ} 52^{\prime} 00 . \quad 59^{\prime \prime} \mathrm{E}$ & 20 \\
\hline
\end{tabular}


Table 2:- Leaf morphometric features of different accessions of L. inrermis.

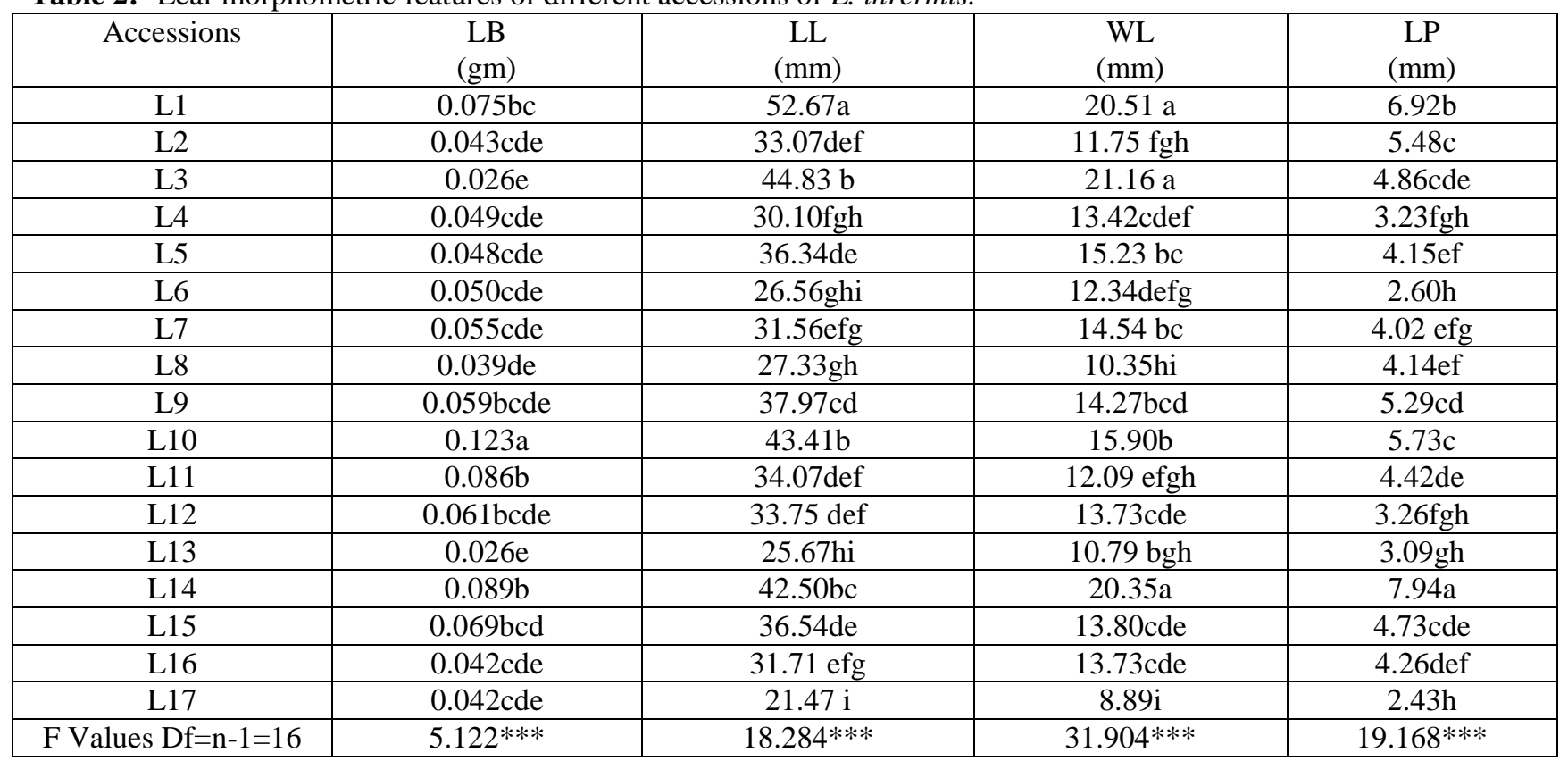

Means within column followed by same letter are not significantly $(\mathrm{p}<0.05)$ different as determined by Duncan's New Multiple Range test (DNMRT).

Table 3:- Floral morphometric features of different accessions of L. inermis

\begin{tabular}{|c|c|c|c|c|c|c|c|}
\hline Accessions & $\begin{array}{c}\mathrm{LS} \\
(\mathrm{mm})\end{array}$ & $\begin{array}{c}\text { WS } \\
(\mathrm{mm})\end{array}$ & $\begin{array}{c}\text { LPT } \\
(\mathrm{mm})\end{array}$ & $\begin{array}{l}\text { WPT } \\
(\mathrm{mm})\end{array}$ & $\mathrm{D}$ CL $(\mathrm{mm})$ & $\begin{array}{l}\mathrm{DCO} \\
(\mathrm{mm})\end{array}$ & $\begin{array}{l}\text { LPD } \\
(\mathrm{mm})\end{array}$ \\
\hline L1 & $2.97 \mathrm{~cd}$ & $1.57 \mathrm{ef}$ & $2.49 \mathrm{fg}$ & $1.62 \mathrm{fg}$ & 4.67fghi & 5.89ef & $3.82 \mathrm{c}$ \\
\hline L2 & $3.11 \mathrm{~cd}$ & $1.38 \mathrm{f}$ & $2.53 \mathrm{fg}$ & $1.29 \mathrm{~h}$ & $4.13 \mathrm{i}$ & 6.10de & $2.84 \mathrm{ef}$ \\
\hline L3 & $3.37 \mathrm{bcd}$ & $1.93 \mathrm{bcd}$ & $2.58 f g$ & $1.33 \mathrm{gh}$ & $4.52 \mathrm{ghi}$ & $4.97 \mathrm{~h}$ & $2.35 f g$ \\
\hline $\mathrm{L} 4$ & $3.27 \mathrm{bcd}$ & $1.86 \mathrm{~cd}$ & $3.49 \mathrm{~b}$ & $3.36 \mathrm{a}$ & $6.03 \mathrm{ab}$ & $7.46 \mathrm{~b}$ & $2.37 \mathrm{fg}$ \\
\hline L5 & $3.40 \mathrm{bcd}$ & $2.09 \mathrm{abc}$ & $3.24 \mathrm{bcd}$ & $1.92 \mathrm{bcd}$ & $5.76 a b c$ & $7.20 \mathrm{bc}$ & $3.62 \mathrm{~cd}$ \\
\hline L6 & $3.43 \mathrm{bc}$ & $2.20 \mathrm{ab}$ & $4.72 \mathrm{a}$ & $3.76 \mathrm{a}$ & $3.59 \mathrm{j}$ & $8.78 \mathrm{a}$ & $2.73 \mathrm{ef}$ \\
\hline L7 & $3.30 \mathrm{bcd}$ & 1.99abcd & $3.12 \mathrm{bcdef}$ & $2.28 \mathrm{bcde}$ & $5.07 \mathrm{defg}$ & $7.10 \mathrm{bc}$ & $1.94 \mathrm{~g}$ \\
\hline L8 & $3.25 \mathrm{bcd}$ & $1.73 \mathrm{de}$ & 2.86defg & 1.76defg & 4.94efgh & $5.14 \mathrm{gh}$ & $2.796 \mathrm{ef}$ \\
\hline L9 & $3.31 \mathrm{bcd}$ & 1.94 bcd & 3.14 bcde & $2.26 \mathrm{bcde}$ & $6.11 \mathrm{a}$ & $6.69 \mathrm{~cd}$ & $3.17 \mathrm{de}$ \\
\hline L10 & $4.20 \mathrm{a}$ & $2.05 \mathrm{abc}$ & $2.55 f g$ & $1.66 f g$ & 4.44hi & $5.31 \mathrm{fgh}$ & $5.32 b$ \\
\hline L11 & $3.32 \mathrm{bcd}$ & $1.93 \mathrm{bcd}$ & $2.98 \mathrm{cdef}$ & $1.75 \mathrm{cdef}$ & $5.31 \mathrm{cde}$ & 5.52efgh & $6.47 \mathrm{a}$ \\
\hline L12 & $3.10 \mathrm{~cd}$ & $1.96 \mathrm{bcd}$ & $3.24 \mathrm{bcd}$ & $1.95 \mathrm{bcd}$ & 5.66abcd & $6.90 \mathrm{bc}$ & $2.95 \mathrm{ef}$ \\
\hline L13 & $2.81 \mathrm{~d}$ & $1.73 \mathrm{de}$ & $3.53 \mathrm{~b}$ & $2.12 b$ & $5.24 \mathrm{cdef}$ & $5.75 \mathrm{efg}$ & $3.13 \mathrm{de}$ \\
\hline L14 & $2.89 \mathrm{~cd}$ & $1.93 \mathrm{~cd}$ & $2.45 \mathrm{~g}$ & $1.51 \mathrm{~g}$ & $5.49 \mathrm{bcde}$ & 5.44efgh & $6.73 a$ \\
\hline L15 & $3.80 \mathrm{ab}$ & $2.25 \mathrm{a}$ & $3.44 \mathrm{bc}$ & $2.18 \mathrm{bc}$ & 5.44 bcde & $6.94 \mathrm{bc}$ & $1.98 \mathrm{~g}$ \\
\hline L16 & $3.29 \mathrm{bcd}$ & $1.85 \mathrm{de}$ & $2.60 \mathrm{fg}$ & $1.62 \mathrm{fg}$ & 5.17cdef $n$ & 6.10de & $2.56 \mathrm{efg}$ \\
\hline L17 & $3.24 \mathrm{bcd}$ & $1.95 \mathrm{bcd}$ & $2.72 \mathrm{efg}$ & $1.97 \mathrm{efg}$ & 5.17cdef & $6.12 \mathrm{de}$ & $2.96 \mathrm{ef}$ \\
\hline $\begin{array}{l}\text { F value } \\
\text { Df }=n-1=16\end{array}$ & $3.287 * * *$ & $5.878 * * *$ & $13.874 * * *$ & $32.649 * * *$ & $12.102 * * *$ & $17.916^{* * *}$ & $49.827 * * *$ \\
\hline
\end{tabular}

Means within column followed by same letter are not significantly $(\mathrm{p}<0.05)$ different as determined by Duncan's New Multiple Range test (DNMRT). 
Table 4:- Fruit variation in different accessions of $L$. inermis

\begin{tabular}{|c|c|c|c|}
\hline Accessions & FL $(\mathrm{mm})$ & WF $(\mathrm{mm})$ & FWT $(\mathrm{gm})$ \\
\hline L1 & $6.81 \mathrm{bc}$ & $6.07 \mathrm{de}$ & $0.13 \mathrm{~d}$ \\
\hline L2 & $4.70 \mathrm{f}$ & $3.86 \mathrm{~g}$ & $0.14 \mathrm{bcd}$ \\
\hline L3 & $6.89 \mathrm{bc}$ & $5.70 \mathrm{e}$ & $0.12 \mathrm{~d}$ \\
\hline L4 & $4.73 \mathrm{f}$ & $4.77 \mathrm{f}$ & $0.12 \mathrm{~d}$ \\
\hline L5 & $6.85 \mathrm{bc}$ & $6.8 \mathrm{c}$ & $0.18 \mathrm{~d}$ \\
\hline L6 & $6.00 \mathrm{~d}$ & $1.58 \mathrm{i}$ & $0.12 \mathrm{~d}$ \\
\hline L8 & $6.14 \mathrm{~d}$ & $5.99 \mathrm{de}$ & $0.15 \mathrm{bcd}$ \\
\hline L9 & $6.21 \mathrm{bc}$ & $6.07 \mathrm{c}$ & $0.24 \mathrm{a}$ \\
\hline L10 & $7.80 \mathrm{a}$ & $7.58 \mathrm{ab}$ & $0.02 \mathrm{e}$ \\
\hline L11 & $7.33 \mathrm{~b}$ & $7.36 \mathrm{ab}$ & $0.17 \mathrm{bcd}$ \\
\hline L12 & $6.48 \mathrm{~cd}$ & $6.78 \mathrm{c}$ & $0.24 \mathrm{a}$ \\
\hline L13 & $6.87 \mathrm{bc}$ & $7.67 \mathrm{ab}$ & $0.13 \mathrm{~cd}$ \\
\hline L14 & $7.10 \mathrm{~b}$ & $6.14 \mathrm{de}$ & $0.16 \mathrm{bcd}$ \\
\hline L15 & $6.87 \mathrm{bc}$ & $2.03 \mathrm{~h}$ & $0.18 \mathrm{bc}$ \\
\hline L17 & $6.27 \mathrm{~d}$ & $7.26 \mathrm{~b}$ & $0.25 \mathrm{a}$ \\
\hline F value & $6.90 \mathrm{bc}$ & $7.78 \mathrm{a}$ & $0.13 \mathrm{~cd}$ \\
\hline
\end{tabular}

Means within column followed by same letter are not significantly $(\mathrm{p}<0.05)$ different as determined by Duncan's New Multiple Range test (DNMRT).

Table 5:- Variability in various seed traits of $L$. inermis accessions

\begin{tabular}{|c|c|c|c|}
\hline Accessions & $\begin{array}{c}\mathrm{SL} \\
(\mathrm{mm})\end{array}$ & $\begin{array}{c}\mathrm{SW} \\
(\mathrm{mm})\end{array}$ & $\begin{array}{l}\text { SWT } \\
(\mathrm{g})\end{array}$ \\
\hline L1 & $1.39 \mathrm{gh}$ & $2.28 \mathrm{def}$ & $0.11 \mathrm{~cd}$ \\
\hline L2 & $1.14 \mathrm{~h}$ & $1.48 \mathrm{~h}$ & $0.13 \mathrm{abcd}$ \\
\hline L3 & $2.06 \mathrm{ef}$ & $2.48 \mathrm{cdef}$ & $0.11 \mathrm{~cd}$ \\
\hline L4 & $2.29 \mathrm{bcde}$ & $2.62 b c$ & $0.19 \mathrm{ab}$ \\
\hline L5 & $1.58 \mathrm{fg}$ & $2.85 \mathrm{ab}$ & $0.10 \mathrm{~cd}$ \\
\hline L6 & $2.06 \mathrm{fg}$ & $2.53 \mathrm{cde}$ & $0.12 \mathrm{bcd}$ \\
\hline L7 & $1.86 \mathrm{bcde}$ & $2.26 \mathrm{efg}$ & $0.088 \mathrm{de}$ \\
\hline L8 & $1.86 \mathrm{cdef}$ & $2.36 \mathrm{cdef}$ & $0.19 a$ \\
\hline L9 & 1.91cdef & $2.83 \mathrm{ab}$ & $0.17 \mathrm{abc}$ \\
\hline L10 & $1.64 \mathrm{fg}$ & $2.57 \mathrm{bcd}$ & $0.16 \mathrm{abc}$ \\
\hline L11 & 2.03 bcde & $2.57 \mathrm{bcd}$ & $0.11 \mathrm{~cd}$ \\
\hline L12 & $2.11 \mathrm{bcd}$ & $3.01 \mathrm{a}$ & $0.06 \mathrm{de}$ \\
\hline L13 & $1.82 \mathrm{def}$ & $2.36 \mathrm{cdef}$ & $0.10 \mathrm{cde}$ \\
\hline L14 & $1.83 \mathrm{def}$ & $2.22 \mathrm{efg}$ & $0.12 \mathrm{bcd}$ \\
\hline L15 & $2.35 \mathrm{ab}$ & $2.94 \mathrm{a}$ & $0.13 \mathrm{bcd}$ \\
\hline L16 & $2.20 \mathrm{bc}$ & $2.03 \mathrm{~g}$ & $0.03 \mathrm{e}$ \\
\hline L17 & $2.66 \mathrm{a}$ & $2.22 \mathrm{fg}$ & $0.08 \mathrm{de}$ \\
\hline $\begin{array}{c}\text { F value } \\
\text { Df }=n-1=16\end{array}$ & $11.00 * * *$ & $16.332 * * *$ & $3.950 * * *$ \\
\hline
\end{tabular}

Means within column followed by same letter are not significantly $(\mathrm{p}<0.05)$ different as determined by Duncan's New Multiple Range test (DNMRT). 
Table 6:- Extracted Eigen values with the first, second and third principal components

\begin{tabular}{|c|c|c|c|}
\hline Characters & PC1 & PC2 & PC3 \\
\hline Leaf Biomass (LB) & 0.007 & -0.002 & -0.031 \\
\hline Length of leaf (LL) & 0.511 & -0.269 & -0.177 \\
\hline Width of leaf (WL) & 0.388 & -0.201 & -0.426 \\
\hline Length of petiole (PL) & 0.24 & -0.332 & 0.117 \\
\hline Length of petal (LPT) & 0.208 & 0.05 & 0.156 \\
\hline Width of petal (WPT) & 0.152 & 0.105 & 0.063 \\
\hline Length of sepal (LS) & 0.199 & 0.359 & 0.072 \\
\hline Width of sepal (WS) & 0.156 & 0.083 & 0.251 \\
\hline Diameter of calyx DCL) & 0.258 & 0.24 & 0.195 \\
\hline Diameter of corolla (DCO) & 0.283 & -0.406 & 0.52 \\
\hline Length of peduncle LPD) & 0.206 & -0.054 & 0.155 \\
\hline Length of fruit (LF) & 0.282 & 0.422 & -0.509 \\
\hline Width of fruit (WF) & 0.271 & 0.022 & 0.034 \\
\hline Weight of fruit (FW) & 0.022 & 0.087 & 0.125 \\
\hline Seed length (SL) & 0.177 & 0.266 & 0.181 \\
\hline Width of seed (SW) & 0.153 & 0.318 & 0.072 \\
\hline Weight of seed (SWT) & 0.031 & 0.03 & 0.03 \\
\hline Eigenvalues & 9.79 & 99.45 & 0.22 \\
\hline Percentage & 99.17 & & 99.67 \\
\hline Cum. Percentage & 99.17 & & \\
\hline
\end{tabular}

Table 7:- Highest loading characters of PCA1, PCA2 and PCA3

Principal Component

First principal component

Morph-metric traits

Variability of highest loaded character are; length of leaf, width of leaf, diameter of corolla, length of fruit, width of fruit, diameter of calyx

Second principal component

Variability of highest loaded characters are; width of fruit, length of peduncle, width of sepal, length of petiole, width of seed

Third principal component

Variability of highest loaded character are; width of fruit and length of petiole

Table 8:- Determination of lawsone content from 17 accessions of L. inermis.

\begin{tabular}{|c|c|}
\hline Accessions & Lawsone $\left(\mathrm{mg} / \mathrm{g}^{-1} \mathrm{dw}\right)$ \\
\hline L1 & $2.23 \pm 0.03 \mathrm{bc}$ \\
\hline L2 & $2.23 \pm 0.03 \mathrm{bc}$ \\
\hline L3 & $2.26 \pm 0.03 \mathrm{bc}$ \\
\hline L4 & $2.30 \pm 0.05 \mathrm{~b}$ \\
\hline L5 & $2.23 \pm 0.03 \mathrm{bc}$ \\
\hline L6 & $2.16 \pm 0.03 \mathrm{bc}$ \\
\hline L7 & $2.13 \pm 0.03 \mathrm{c}$ \\
\hline L8 & $2.13 \pm 0.03 \mathrm{c}$ \\
\hline L9 & $2.23 \pm 0.06 \mathrm{bc}$ \\
\hline L10 & $2.43 \pm 0.03 \mathrm{a}$ \\
\hline L11 & $2.23 \pm 0.03 \mathrm{bc}$ \\
\hline L12 & $2.26 \pm 0.06 \mathrm{bc}$ \\
\hline L13 & $2.26 \pm 0.03 \mathrm{bc}$ \\
\hline L14 & $2.46 \pm 0.03 \mathrm{a}$ \\
\hline L15 & $1.86 \pm 0.03 \mathrm{~d}$ \\
\hline L16 & $1.66 \pm 0.03 \mathrm{e}$ \\
\hline L17 & $1.06 \pm 0.03 \mathrm{f}$ \\
\hline Treatment $(\mathrm{n}-1)=16$ & $67.31 * * *$ \\
\hline
\end{tabular}

***Significant at $\mathrm{p}<0.001$ level; Means within column followed by same letter are not significantly $(\mathrm{p}<0.05)$ different as determined by Duncan's New Multiple Range test (DNMRT). 


\section{Principal Component Analysis:-}

PCA is a powerful and the most preferred multivariate statistical technique that carries out a data reduction routine among several interdependent variables, while retaining those characteristics of the dataset that contribute most to its variance, by keeping lower-order principal components and ignoring higher-order ones. In present study, principal component analysis included Eigen analysis conducted using 17 characters of 17 collections and Eigen values and percentage was tabulated (Table 6). The first, second and third principal component accounted $99.67 \%$ variability. Based on analysis, Eigen values for different parameters were extracted and presented (Table 6).

The traits accounting for most of the variation expressed in the first Principal Component (PC1) were length of leaf ( $\mathrm{LL}=0.511$ ), width of leaf ( $\mathrm{WL}=0.388)$, diameter of corolla ( $\mathrm{DCO}=0.283)$, length of fruit $(\mathrm{LF}=0.82)$, width of fruit $(\mathrm{WF}=0.271)$ and diameter of calyx $(\mathrm{DCL}=0.258)$. Second principal component was formed by variability of highest loaded character such as width of fruit $(\mathrm{WF}=0.422)$, length of peduncle $(\mathrm{LPD}=-0.406)$, width of sepal $(\mathrm{WS}=0.359)$ length of petiole ( $\mathrm{PL}=-0.332)$ and width of seed (Table 6). Third principal component was formed by variability of highest loaded character such as width of fruit $(\mathrm{WF}=-0.509)$ and length of petiole $(\mathrm{PL}=-0.426)$. There was previous report that first three components explained $34.16 \%$ of the total variation in Prunus scoparia (KhadiviKhub and Anjam 2014). Principal component analysis revealed that the first three components contributed to most of total variation that attributes highest variation between the studied collections and had the greatest impact (Iezzoni and Pritts 1991). In Theobroma cacao L the first three principal components accounted for $78.3 \%$ of the total phenotypic variations (Bekele1 et al. 2006).

Principal Component Analysis was used to examine the level of diversity in the germplasm and to rank the contributions of the variables to it. When three principal components (PC1, PC2 and PC3) represent a high proportion of the variance of the samples under study, a plot of their scores can be made and would approximately show the relative groupings of the samples or give a fair indication of the overall distribution of the data and uncover any interesting patterns exhibited (Mardia et al. 1979). Based on PCA results,length of leaf and width of leaf, diameter of corolla, length and width of fruit, diameter of calyx, length of peduncle, width of sepal, length of petiole, length and width of seed, diameter of calyx and length of sepal were among the most important descriptors which accounted for more genotypic variation expressed in this population. These descriptors were therefore considered as most useful for recording the variability among $L$. inermis accessions. Hence, principal component analysis was used to identify the most significant variables in the data set. Previously, PCA had been used to evaluate germplasm of different species: olive (Cantini et al. 1999), pomegranate (Mars and Marrakchi 1999), loquat (Badenes et al. 2000; Martı 'nez-Calvo et al. 2008) apricot (Ruiz and Egea 2008) and clusterbean (Morris 2010). Contribution of character towards principal component factors were studied in clusterbean (Manivannan 2016). PCA had also been used to establish genetic relationships among cultivars and genotypes, to study correlations among traits and to evaluate germplasm of different species (Horvath et al. 2008; Sorkheh et al. 2009; Rakonjac et al, 2010; Khadivi- Khub et al. 2012, 2013).

Length of petal and diameter of corolla were the quantitative traits which showed striking variation. These results complement with those of the PCA. In Theobroma cacaostriking geographical variation in floral morphology and style-morph ratios was recorded (Bekele 1994; Bekele 2006). Variation in floral and vegetative traits enabled statistical prediction of morphofrequency variation among populations. These results complement those of the PCA. In contrast to these findings, workers (Cui et al. 2001) opine effectiveness of morphological descriptors to discriminating among genotypes and for studying phenotypic diversity. As a measure of reducing the multiple variables to a handful of principal components that explain hierarchically lowering levels of variance components, the PCA of the qualitative data derived from 17 genotypes, revealed at least three independent variable groupings accounting to $99.67 \%$ of total variation (Eigen value more than 1). This is evident from the extraction of three lower-order principal components from the PCA, which is explained by the presence of high number of independent variables. The PCA is highly effective as a data reduction tool, when variables are inter-correlated (Pearson 1901). These independent components therefore would be used for effective classification of the genotypes.

\section{Cluster Analysis:-}

Hierarchical cluster analysis allowed the assessment of similarity or dissimilarity and classified some of the relationships among $L$. inermis genotypes. The factors corresponding to four PCs were subjected to cluster analysis based on Euclidean distances and grouped by unweighted paired group method using arithmetic average (UPGMA). The dendrogram depicted two broad distinct principle clusters (Figure1). First principal cluster accounted two genotypes (L6 and L14) collected from Thrissur and Wayanad collection. They are the most diverged from other 
collections (Euclidian distance: 0.93). Collection L6 and L14 contribute dissimilarity index with (0.368) since L6 shows highly significant in quantitative traits such as length of petal, width of petal and diameter of corolla. Collection L6 also accounted least variation in diameter of calyx and width of fruit. The collection L14 showed maximum in width of leaf, length of petiole, length of peduncle and least variation in length of petal and width of petal. Collection L6 showed most significance in floral characters like length of petal $(4.22 \mathrm{~mm})$, width of petal $(3.76 \mathrm{~mm})$, diameter of corolla $(8.70 \mathrm{~mm})$ and least value also recorded in L6 with length of petiole $(2.60 \mathrm{~mm})$, diameter of calyx $(3.59 \mathrm{~mm})$ and width of fruit $(1.58 \mathrm{~mm})$ compared to all other collections. Henna collection L14 shows most significance in leaf characters such as width of leaf $(20.35 \mathrm{~mm})$, length of petiole $(7.94 \mathrm{~mm})$ and length of peduncle $(6.73 \mathrm{~mm})$ and least variations in length of petal $(2.45 \mathrm{~mm})$ and width of petal $(1.51 \mathrm{~mm})$. As such collection L6 accounted most significant in floral morphology and L14 in leaf morphology. Seed and fruit morphology showed low level similarity in all the selected parameters. Seed weight recorded $(0.12 \mathrm{~g})$ in both the L6 and L14 collections. Collections L5 and L9 showed least variation with Euclidian distance 0.14 with dissimilarity index 0.156. Hence, L5 and L9 seems to be the most similar collection due to related values in leaf length $(36.34 \mathrm{~mm}, 37.97 \mathrm{~mm})$, width of leaf $(15.23 \mathrm{~mm}, 14.27 \mathrm{~mm})$, length of sepal $(3.41 \mathrm{~mm}, 3.31 \mathrm{~mm})$, length of petal $(3.24 \mathrm{~mm}, 3.14 \mathrm{~mm})$ and seed width $(2.85 \mathrm{~mm}, 2.83 \mathrm{~mm})$. Second principal cluster subdivided in to two clusters and it is again sub divided to different sub clusters. In the second principal cluster, L2 was most diverged one with the Euclidian distance: 0.46 . The collection L2 showed least values for width of sepal, length of fruit, length and width of seed. First principal cluster accounted L6 and L14 shows dissimilarity index with second principal cluster L2 is $(0.53,0.547)$. Dissimilarity index of L14 with L13 is 0.714 . Second principal cluster again subdivided in to two sub clusters. The first sub cluster occupied collections of L1, L3, L10, L11 and L13. Among the first main sub cluster L3 accounted most diverged one with (Euclidian distance: 0.26). The collection L3 showed maximum in width of leaf and minimum in leaf biomass and diameter of corolla. Collection L3 and L14 showed dissimilarity index (0.646). Second sub cluster subdivided and comprises collections of L4, L5, L7, L8, L12, L15, L16 and L17. Among the collections L17 occupied most diverged with (Euclidian distance: 0.40). Collection L17 accounted highest value in seed length and least in leaf length, width of leaf and length of petiole. The dissimilarity index between L17 and L1 is 0.700 and with L13 is 0.711 . Although, the morphological dendrogram generated from similarity or genetic distance matrices has provided an overall pattern of variation as well as the degree of relatedness among collections. Diverse result could be obtained in morphological grouping, when experiments were repeated owing to variations in environmental conditions such as soil type, soil fertility levels (Steel 1972) light, temperature and moisture regime (Summerfield and Huxley 1973; Morakinyo and Ajibade 1998). The clustering pattern obtained in dendrogram should be further confirmed using the supporting evidence from PCA scatter plot.

The scattered plot (Figure 2) based on PCoA analysis showed similar results as that of UPGMA dendrogram. Scatter plot was prepared according to the Principle component analysis that reflected relationship among accessions in terms of phenotypic resemblance and morphological characteristics. Results of scatter plot supported the results of cluster analysis and collections were distributed in four sides of plot (Fig. 2). Collections L6 and L14 were grouped in one quadrant and lie distant from other collections as depicted by the dendrogram. Collections which show most similarity value were seen grouped in one quadrant of which collections L5 and L9 lie very closely as depicted by the dendrogram and similarity values. However, the morphological studies confirmed the relationship between seventeen collections of $L$. inermis.

Multivariate analysis of principal components and cluster analysis based on morphological traits performed to determine the level of variability and the relationship among the collections.

\section{Quantification of lawsone}

The lawsone content considered as the major quality parameter of L. inermis which is significantly influenced by weather and its geographical distribution. In this study spectrophotometric determination of lawsone content in 17 collections of $L$. inermis showed significant $(\mathrm{P}<0.001)$ variation between collections (Table 9). Estimation of lawsone was done by methanol as solvent. Methanol was found to be most suitable solvent to obtain the higher yields for naphthoquinones extraction (Wu et al. 1998; Marczak et al. 2005; Hu et al. 2006). Lawsone content registered significantly $(\mathrm{P}<0.05)$ high concentration in collections L14 $\left(2.46 \mathrm{mg} / \mathrm{g}^{-1} \mathrm{dw}\right)$ and L10 $\left(2.43 \mathrm{mg} / \mathrm{g}^{-1} \mathrm{dw}\right)$ compared to other collections. Collections L1, L2, L3, L5, L6, L9, L11, L12 and L13 did not show any significant $(\mathrm{P}<0.05)$ difference in lawsone content. Upadhyay et al. (2010) confirmed that the quantification lawsone extracted from leaves of $L$. inermis collected in different seasons showed variation in the active ingredient lawsone. Lawsone is not only the colouring agent of the plant but also attributes numerous phyto pharmacological properties. The least 
lawsone content was recorded in $\mathrm{L} 17\left(1.06 \mathrm{mg} / \mathrm{g}^{-1} \mathrm{dw}\right)$. The overall percentage of lawsone ranged between 1.06 to $2.46 \mathrm{~m} / \mathrm{g}^{-1} \mathrm{dw}$.

In the previous reports various methods viz., spectrophotometry, thin layer chromatography (TLC), high pressure liquid chromatograpy (HPLC) and high pressure thin layer chromatography (HPTLC) were employed for quantitative analysis of lawsone (Dhiman et al. 2012 ). Ashnagar and Shiri (2011) made use of infra red spectroscopy (IR) and TLC for isolation of lawsone, whereas in the present investigation quantification of lawsone was done by using spectrophotometric method. Present results shows variations in lawsone content in L. inermis among the collections may influenced by environmental factors and morphological variation is apparently the result of an adaptive response to the environment such as variation in latitudinal and altitudinal range or by contrasting climatic conditions. It has been proposed that lawsone can be used as a non-oxidizing hair colouring agent at a maximum concentration of $1.5 \%$ (Gevrenova 2010). Henna finds with numerous applications in both therapeutic and cosmetic industries. The key role behind its efficiency is being played by its active constituent lawsone, which can be further explored by incorporating this compound in to novel dosage forms.

Morphological variations in different collections were investigated by the relationship between morphological and biochemical markers were previously reported in Bacopa monnieri (Roshini et al., 2014) and Bixa orellana (Joseph and Siril 2014). In the present study, biochemical marker lawsone was quantified by spectrophotometric method and showed distinct variation among the collections. Lawsone content was high in L14 (2.46mg/g $\left.{ }^{-1} \mathrm{dw}\right)$ and L10 $\left(2.43 \mathrm{mg} / \mathrm{g}^{-1} \mathrm{dw}\right)$ procured from Wayanad and Idukki respectively.. Morphometric study of leaf with all the characters along with lawsone content did not show any significant association. However, among all the collections made, length of petiole seem to be significant in L14 which can be included as important character were the lawsone is primarily produced and present in petiole of the plant. There was similar report that lawsone content did not shown significant association with other characters of the plant (Singh et al. 2008). The study revealed that all the morphometric parameters showed morphological variation in the L. inermis. These differences were strongly influenced by environmental factors (soil texture, soil chemical characteristics and annual rainfall) and geographical distribution.

\section{Conclusion:-}

Present study forward morphological and biochemical variation in 17 collections of L. inermis that warrant further development of cultivars. The data showed that germplasm resources present a wide range of diversity for morphological traits. The investigations were also very useful in choosing the most precious accessions for further breeding programmes. The superiority of L14 collection with regard to total lawsone content and other leaf characters this accession attributes to genetic distinction compared to other collections. Substantiating to this, the dendrogram and cluster analysis clearly separated the collection L14 from rest. In this regard further studies need to be undertaken to depict genetic variation among collections using molecular markers. Based on superiority of lawsone content and other desirable traits such aswidth of leaf, length of petiole, length of peduncle collection L14 elevated as superior collection having the potential to use in the vegetative multiplication and improvement programmes. The present study clearly emphasis the power of morphological markers in characterization and utilization of plant genetic resource.

\section{Acknowledgments:-}

The authors thank Dr. Suhara Beevy S, Associate Professor and Head, Department of Botany, University of Kerala, for providing research facilities. PCS thank Kerala State Welfare Board for providing research grant (B314931/06/11/2014). 


\section{References:-}

1. Abdi, A., Bekele, E., Asfaw, Z., Teshome, A. (2002): Patterns of morphological variations of sorghum (Sorghum bicolor (L.) Moench) landraces in quantitative characters in North Showa and South Welo, Ethiopia. Hereditas., 137: 161-172.

2. Anju, D., Kavita, S., Goyal, J., Munish, G., Asha, S. (2012): Determination of lawsone concentration in fresh and dried leaves of Lawsonia inermis L. and its quantitative analysis. Journal of Pharmaceutical and Scientific Innovation., 1: 17-20.

3. Ashnagar, A., Shiri, A. (2011): Isolation and characterization of 2-hydroxy-1,4 naphthoquinone (lawsone) from the powdered leaves of henna plant marketed in Ahwaz city of Iran. International Journal of Chem Tech Research., 3: 1941-1944.

4. Badenes, ML., Martı 'inez-Calvo, J., Lla 'cer, G. (2000): Analysis of a germplasm collection of loquat (Eriobotrya japonica Lindl.). Euphytica., 114: 187-194.

5. Bekele, F.L., Bekele, I. (1994): A sampling of the phenetic diversity in the International Cocoa Genebank of Trinidad. Crop Sci., 36: 57-64.

6. Bakkali, A.T., Jaziri, M., Fories, A., Vander-Heyden, Y., Vanhaelen, M., Homes, J. (1997): Lawsone accumulation in normal and transformed cultures of henna, Lawsonia inermis. Plant Cell Tiss Organ Cult 51: 83-87.

7. Bekele, F.L. (2006): Patterns of morphological variation in a sample of cacao (Theobroma cacao L.) germplasm from the International Cocoa Gene bank, Trinidad. Genetic Resources and Crop Evolution., 53: 933-948.

8. Beuningen, L.T., Busch, R.H. (1997): Genetic diversity among North American spring wheat cultivars: III. Cluster analysis based on quantitative morphological traits. Crop Sci., 37: 981-988.

9. Cantini, C., Cimato, A., Sani, G. (1999): Morphological evaluation of olive germplasm present in Tuscany region. Euphytica.,109: 173-181.

10. Chand, K., Jangid, B. L. (2007): Economic viability of henna in semi-arid Rajasthan. Agricultural Economics Research Review.,20: 137-146.

11. Chaudhary,G., Goyal, S.,Poonia, P. (2010): Lawsonia inermis Linn. A Phytopharmacological Review. International Journal of Pharmaceutical Sciences and Drug Research., 2: 91-98.

12. Cui Z., Carter T.E., Burton J.W., Wells R. (2001): Phenotypic diversity of modern Chinese and North American soybean cultivars. Crop Sci., 41: 1954-1967.

13. Dhiman, A., Sharma, K., Goyal, J., Garg, M., Sharma, A. (2012): Determination of lawsone content in fresh and dried leaves of Lawsonia inermis Linn. and its quantitative analysis by hptlc. Journal of Pharmaceutical and Scientific Innovation., 1(2): 17-20.

14. Elfadl, E., Reinbrecht, C., Claupein, W. (2010): Evaluation of phenotypic variation in a worldwide germplasm collection of safflower (Carthamus tinctorius L.) grown under organic farming conditions in Germany. Genet Resour Crop Evol., 57: 155-170.

15. Fufa,H., Baenziger, P.S., Beecher, B.S., Dweikat, I., Graybosch, R.A., Eskridge, K.M. (2005) Comparison of phenotypic and molecular marker-based classifications of hard red winter wheat cultivars. Euphytica., 145: 133146.

16. Gallo, R.F., Multari, G., Giambenedetti, M., Federici, E. (2008): Chemical fingerprinting of Lawsonia inermis L. using HPLC,HPTLC and densitometry.Phytochem. Anal., 19: 550-559.

17. Gerrano, A.S., Labuschagne, M.T., van Biljon,A., Shargie, N.G. (2014): Genetic diversity assessment in sorghum accessions using qualitative morphological and amplified fragment length polymorphism marker. Sci Agric (Piracicaba, Braz.)., 71: 394-401.

18. Gevrenova, R. (2010): Determination of natural colorants in plant extracts by high performance liquid chromatography. Journal of the Serbian Chemical Society., 75: 903-915.

19. Gower, J.C. (1996): Some distance properties of latent root and vector method used in multivariate analysis. Biometrika., 53: 325-338.

20. Horvath, A., Christmann, H., Laigret, F. (2008): Genetic diversity and relationships among Prunus cerasifera (cherry plum) clones. Botany., 86: 1311-1318.

21. Hu, Y., Jiang, Z .H., Leung, K. S. Y., Zhao, Z ,Z. (2006): Simultaneous determination of naphthoquinone derivatives in Boraginaceous herbs by high-performance liquid chromatography. Analytica Chimica Acta., 577: 26-31.

22. Iezzoni, AF., Pritts, M.P. (1991): Applications of principal components analysis to horticultural research. HortScience.,26: 334-338.

23. Joseph, N., Siril E.A. (2014): Evaluation and selection of elite annatto (Bixa orellana L.) and identification of RAPD markers associated with yield traits. Brazilian Journal of Botany., 37: 1-8. 
24. Khadivi-Khub, A., Jafari, H.R., Zamani, Z. (2013): Phenotypic and genotypic variation in Iranian sour and duke cherries. Trees., 27: 1455-1466.

25. Khadivi-Khub, A., Zamani, Z., Fatahi, M.R . (2012): Multivariate analysis of Prunus subgen. Cerasus germplasm in Iran using morphological ariables. Genet Resour Crop Evol., 59: 909-926.

26. Manivannan, A., Anandakumar, C, R., Ushakumari, R., Dahiya, G.S. (2016): Characterization of Indian clusterbean (Cyamopsis tetragonoloba (L.) Taub.) genotypes using qualitative morphological traits. Genet Resour Crop Evol., 63: 483-493.

27. Marczak, L., Kawiak, A., Lojkowska, E., Stobiecki, M. (2005) : Secondary metabolites in in vitro cultured plants of the genus Drosera. Phytochemical Analysis16: 43-49.

28. Mardia, KV., Kent, J.T., Bibby, J.M. (1979): Multivariate Analysis London : Academic Press.

29. Mars, M., Marrakchi, M. (1999) Diversity of pomegranate (Punica granatum L.) germplasm in Tunisia. Genet Resour Crop Evol., 46: 461-467.

30. Martı 'nez-Calvo, J., Gisbert, A.D., Alamar, M.C., Hernandorena, R., Romero, C., Lla 'cer, G., Badenes, M.L. (2008): Study of a germplasm collection of loquat (Eriobotrya japonica Lindl.) by multivariate analysis. Genet Resour Crop Evol.,55: 695-703.

31. McCormick, K.M., Norton, R.M., Eagles, H.A. (2009): Phenotypic variation within a fenugreek (Trigonella foenum-graecum L.) germplasm collection. II. Cultivar selection based ontraits associated with seed yield. Genet Resour Crop Evol., 56: 651-661.

32. Morakinyo. J.A., Ajibade, S.R. (1998): Characterization of segregants of an improved cowpea lines IT84K124-6.Nig. J Sci., 32: 27-32.

33. Morris, J.B. (2007): Swordbean (Canavalia ensiformis (L.) DC.) genetic resources regenerated for potential medical, nutraceutical and agricultural traits. Genet Resour Crop Evol., 54: 585-592.

34. Morris, J.B. (2008): Macrotyloma axillare and M. uniflorum: descriptor analysis, anthocyanin indexes, and potential uses. Genet Resour Crop Evol., 55: 5-8.

35. Morris, J.B. (2009): Characterization of butterfly pea (Clitoria ternatea L.) accessions for morphology, phenology, reproduction and potential nutraceutical, pharmaceutical trait utilization. Genet Resour Crop Evol., 56: $421-427$.

36. Morris, J.B. (2009): Characterization of sesame (Sesamum indicum L.) germplasm regenerated in Georigia, USA. Genet Resour Crop Evol., 56: 925-936.

37. Morris, J.B. (2010): Morphological and reproductive characterization of guar (Cyamopsis tetragonoloba) genetic resources regenerated in Georgia, USA. Genet Resour Crop Evol., 57: 985-993.

38. Nikolic, D., Rakonjac,V., Milatovic, D., Fotiric, M. (2010): Multivariate analysis of vineyard peach (Prunus persica (L.) Batsch.) germplasm collection. Euphytica., 171: 227-234.

39. Pearson, K. (1901): On lines and planes of closest fit to systems of point in space. Philosoph Mag., 2: $559-572$.

40. Rakonjac, V., Aksic, M., Nikolic, D., Milatovic, D., Colic, S. (2010): Morphological characterization of 'Oblacinska' sour cherry by multivariate analysis. Sci Hort., 125: 679-684.

41. Roshni, L.S., Gangaprasad, A., Siril, E.A. (2014): Evaluation of variability in Bacopa monnieri (L.) Pennell using morphological and biochemical markers. International Journal of Applied Research in Natural Products., 7(2): 25-31.

42. Rosso, B.S., Pagano, E.M. (2001): Collection and characterization of naturalized populations of white clover (Trifolium repens L.) in Argentina. Genet Resour Crop Evol., 48: 513-517.

43. Rubio, J., Cubero, J.I., Martin, L.M., Suso, M,J., Flores, F. (2004): Biplot analysis of trait relations of white lupin in Spain. Euphytica., 135:217-224.

44. Ruiz, D., Egea J. (2008): Phenotypic diversity and relationships of fruit quality traits in apricot (Prunus armeniaca L.) germplasm. Euphytica., 163:143-158.

45. Rumbaugh, M.D., Graves, W.L., Caddel, J.L., Mohammad, R.M. (1988): Variability in a collection of alfalfa germplasm from Morocco. Crop Sci., 28: 605-609.

46. Singh, M., Jindal, S,K., Sivadasan, R. (2008): Genetic Variability in the Germplasm of Mehndi (Lawsonia inermis). Annals of Arid Zone., 47: 151-154.

47. Sorkheh, K., Shiran, B., Rouhi, V., Asadi, E., Jahanbazi, H., Moradi, H., Gradziel, T.M., Martinez-Go 'mez, P. (2009): Phenotypic diversity within native Iranian almond (Prunus spp.) species and their breeding potential. Genet Resour Crop Evol.,56: 947-961.

48. Steel, W.M. (1972): Cowpeas in Nigeria .Ph.D thesis, p.241. University of Reading, England.

49. Summerfield, R.J., Huxley, P.A. (1973): Day length and night temperature sensitivity screening of selected cowpea and soybean cultivars. Reading University / IITA International Communication No5. Reading, England. 
50. Szamosi, C., Solmaz, I., Sari, N., Barsony, C. (2009): Morphological characterization of Hungarian and Turkish watermelon (Citrullus lanatus (Thunb.) Matsum. Et Nakai) genetic resources. Genet Resour Crop Evol., 56: 1091-1105.

51. Tuinstra, M.R., Grote, E.M., Goldsbrough, P.B., Ejeta, G. (1996): Identification of quantitative trait loci associated with preflowering drought tolerance in sorghum. Crop Sci 36: 1337-1344.

52. Upadhyay, B., Dhaker, A. K., Kumar, K. S. A. (2010): Phytochemical analysis and influence of edaphic factors on lawsone content of Lawsonia inermis L. Journal of Phytology.,2: 47-54.

53. Wu, T, S., Hsu, H. C., Wu, P, L., Leu, Y, L., Chan,Y, Y., Chern, C,Y., Yeh, M ,Y., Tien, H, J. (1998): Naphthoquinone esters from the root of Rhinacanthus nasutus. Chemical and Pharmaceutical Bulletin., 46: 413418. 